\title{
BENEFICIAL ROLE OF BAGASSE BIOCHAR ON MAIZE PLANTS GROWN IN SANDY SOIL
}

\author{
M. Ayman ${ }^{\text {* }}$, Sh. Metwally ${ }^{1}$, M. El-Mancy ${ }^{1}$, A. Hassan ${ }^{1}$ and A. Abd alhafez ${ }^{2}$ \\ 1- Water \& Soil Dep., Faculty of Technology \& Development, Zagazig \\ University, Egypt. Email:mayman@zu.edu.eg \\ 2 - Faculty of Agriculture, New valley University, Egypt.
}

\begin{abstract}
A pot experiment was conducted in a wired greenhouse under local weather conditions at the Faculty of Technology \& Development greenhouses, Zagazig University, Zagazig, Egypt. Maize plants were used as an indicator for the examination of produced bagasse biochar effects on soil properties and maize plants growth in sandy soil. Bagasse biochar was mixed with soil in rates of $0,1,2.5,5,10 \%$ and randomized complete-plot design with three replicates.

Forty days after sowing, maize plants were estimated for chlorophyll content, root depth, plant height. Some soil properties such as particles density (PD), bulk density (BD), water-holding capacity (WHC), soil porosity, organic matter (OM), electrical conductivity (EC) and $\mathrm{pH}$ were determined. Maize plants were dried, milled and analyzed for $N, P, K$ and Si. The obtained results indicated to that application of bagasse biochar significantly improved soil physio-chemical properties such as $P D, B D$, porosity, WHC, OM and maize $N, P, K$ and Si contents. Also, biochar led to improving maize plants growth, chlorophyll content, roots depth and maize height.

Conclusively, it can be concluded that the use of bagasse biochar in amending sandy soil caused a significant increase in maize plants growth and available nutrients uptake.
\end{abstract}

Keywords: Biochar; Maize plants; Germination; Soil properties; Sandy soil.

\section{INTRODUCTION}

Biochar is a carbonaceous, solid, and recalcitrant compound derived from the pyrolysis of waste biomass. Its yield and properties are strongly influenced by pyrolysis conditions and feedstock composition (Pandey et al., 2020). It is a carbon-rich product that is obtained by the burning of biomass, produced during slow thermal decomposition of biomass at temperatures from $300-1000{ }^{\circ} \mathrm{C}$ under zero or low oxygen conditions (Joseph and Lehmann, 2009; Sohi et al., 
2010; Pandey et al., 2020). Also, owing to its low-cost, presence of surface functional groups, porosity, and moderate surface area, biochar is considered as a support material for improving soil properties and immobilizing the enzymes where a part of the biomass is transformed into gaseous, liquid, solid compounds. The biochar remains as a concrete mass of stable carbon (Teßin, 2016; Pandey et al., 2020). Farias et al. (2018) and Sarfraz et al. (2019) found that the application of biochar as a soil conditioner can have environmental and farming benefits. Additionally, it will be greatly important to define guidelines to produce biochar from several feedstocks and pyrolysis methods, and also to have an agreeable standardized classification system to indicate product composition and characteristics (Novotny et al., 2015; Sarfraz et al., 2019). Several studies have reviewed the influence of pyrolysis temperature on the chemical and physical characteristics of residue sludge biochar. Also, the correlation was difficult between pyrolysis temperature and the agroenvironmental properties of biochar (Joseph and Lehmann, 2009; Sohi et al., 2010; Pandey et al., 2020).

Biochar is a substance that production by pyrolysis of feedstock under oxygen-limited conditions at temperatures between 350 and $600{ }^{\circ} \mathrm{C}$ (Sohi et al., 2010). Biochar is a useful material for the soil where leads to improvements of soil physical and chemical properties such as water holding capacity, surface area, improve soil texture, bulk density, soil porosity and chemical properties such as cation and anion exchange capacity and adsorption of nutrients for soil solution in sandy soil (Glaser et al., 2002; Aslam et al., 2014; Pandey et al., 2020). Other studies confirmed that the biochar led to improving physical and chemical characteristics of several textural soils. Biochar is considered an active and positive substance for most of the soil's strategies of soil improvement in the long term. Biochar could amend soil physical characteristics including porosity and water holding capacity, as well as soil bulk density (Aslam et al., 2014; Lu et al., 2014; Nelissen et al., 2015; Huang et al., 2019), and enhance soil chemical properties (Glaser et al., 2002; Lehmann et al., 2011).

Therefore, this study aimed to: (i) to produce biochar from bagasse using a simple and cost-effective method for use in agricultural purposes. (ii) to evaluate characteristics for the produced biochar. (iii) to elucidate the role of biochar in amend mending and improving some physical and chemical properties of sandy soil.

\section{MATERIALS AND METHODS}

\section{Biochar production:}

Biochar was produced from bagasse at $500^{\circ} \mathrm{C}$ in an oxygen-free kiln (Kiln technology). Bagasse was washed with tap water several times, air-dried 
and cut into small parts, packed in an internal container, fuel was ignited in an external container at overnight, then biochar was collected, milled, sieved and added to sandy soil.

\section{Experiment setup:}

A pot experiment was conducted in a wired greenhouse under local weather conditions at the Faculty of Technology \& Development greenhouse farm, Zagazig University (latitude $30^{\circ} 35^{\prime} 23.7^{\prime \prime} \mathrm{N}$, longitude $31^{\circ} 28^{\prime} 53.2^{\prime \prime} \mathrm{E}$ (Geohack, 2020)), Zagazig City, Sharquia Governorate, Egypt. Soil samples were transported into the greenhouses farm, air-dried, ground and passed through a $2-\mathrm{mm}$ sieve. Soil samples were mixed by the biochar, then packed into pots $(25 \mathrm{~cm}$ in diameter and $30 \mathrm{~cm}$ in height). The application rates of biochar $0,1,2.5,5,10 \%(\mathrm{w} / \mathrm{w})$ were uniformly mixed with a $6 \mathrm{~kg}$ soil pot $^{-1}$ and the recommended doses of N, P, and $\mathrm{K}$ were added to all pots. Seeds of maize (Zeya mays L. CV. 166) were obtained from the Maize Research Department, Crops Research Institute, Agriculture Research Centre, Giza, Egypt. The experimental design was laid to in randomized complete -block design with three replicates. Before sowing, pots were wet to about $150 \%$ of field capacity by tap water. Subsequently, soil moisture was kept at $70-80 \%$ of field capacity until sowing. Three grains were sown in each pot on $10^{\text {th }}$ May 2019. Fifteen days after sowing, seedlings were thinned to one plant per pot. Pots were regularly irrigated with tap water and kept at $70 \%$ of soil waterholding capacity. Forty days after sowing, plants were collected from each plot to estimate the depth of roots, shoot height, chlorophyll and biomass per pot $^{-1}$, as well as N, P, K and Si contents in shoots and roots' were also determined.

\section{Experimental design and treatments:}

A pot experiment was carried out with five rates 0.0, 1.0, 2.5, 5.0 and $10.0 \%(\mathrm{w} / \mathrm{w})$ of the produced biochar were applied as in sandy soil. The experimental design was randomized complete plot design with three replicates. The initial basic properties of the studied soil and some characteristics of biochar are presented in Tables 1 and 2 .

\section{Analytical procedures:}

Particle size distribution, water-holding capacity, particle density, bulk density, soil porosity, $\mathrm{EC}, \mathrm{pH}, \mathrm{CEC}, \mathrm{CaCO}_{3}, \mathrm{OM}$, and extractable $\mathrm{N}, \mathrm{P}, \mathrm{K}$ and Si for both soil and biochar were analyzed according to ( Estefan et al., 2013). Maize plant samples were oven-dried at $70^{\circ} \mathrm{C}$ to a constant weight. The ovendried samples were ground and wet-digested in using a mixture of $\mathrm{H}_{2} \mathrm{SO}_{4}$ and $\mathrm{H}_{2} \mathrm{O}_{2}$ at $420{ }^{\circ} \mathrm{C}$ for chemical analyses according to (Parkinson and Allen, 1975). 
Table (1): Some physio-chemical characteristics of used biochar

\begin{tabular}{|c|c|}
\hline Properties & Result \\
\hline EC $\left(1: 10\right.$ extract, $\left.\mathrm{dS} \mathrm{m}^{-1}\right)$ & 1.82 \\
\hline pH (1:10 suspension) & 8.01 \\
\hline Surface area $\left(\mathbf{m}^{2} \mathrm{~g}^{-1}\right)$ & 123.12 \\
\hline CEC $\left(\mathrm{cmole}_{(+)} \mathrm{kg}^{-1}\right)$ & 66.07 \\
\hline Ash contents $\left(\mathrm{g} \mathrm{kg}^{-1}\right)$ & 62.63 \\
\hline $\mathrm{N}\left(\mathrm{g} \mathrm{kg}^{-1}\right)$ & 8.71 \\
\hline$P \quad\left(\mathrm{~g} \mathrm{~kg}^{-1}\right)$ & 1.78 \\
\hline$K \quad\left(\mathrm{~g} \mathrm{~kg}^{-1}\right)$ & 6.79 \\
\hline $\mathrm{Ca}\left(\mathrm{g} \mathrm{kg}^{-1}\right)$ & 7.02 \\
\hline $\operatorname{Mg}\left(\mathrm{g} \mathrm{kg}^{-1}\right)$ & 4.01 \\
\hline
\end{tabular}

Table (2): Some physio-chemical properties of the investigated soil.

\begin{tabular}{|c|c|}
\hline $\begin{array}{c}\text { Properties } \\
\end{array}$ & Result \\
\hline \multicolumn{2}{|l|}{ Particle size distribution $\left(\mathrm{g} \mathrm{hg}^{-1}\right) *$} \\
\hline Sand & 86.12 \\
\hline Silt & 4.23 \\
\hline Clay & 9.65 \\
\hline Textural class & Sandy \\
\hline Bulk density $\left(\mathrm{g} \mathrm{cm}^{-3}\right)$ & 1.74 \\
\hline PD $\left(\mathrm{g} \mathrm{cm}^{-3}\right)$ & 2.65 \\
\hline EC (in soil paste extract, $\mathrm{dS} \mathrm{m}^{-\mathbf{1}}$ ) & 1.34 \\
\hline pH (in 1 soil: 2.5 water suspension) & 7.33 \\
\hline $\mathrm{CaCO}_{3}\left(\mathrm{~g} \mathrm{Kg}^{-1}\right)$ & 17.22 \\
\hline CEC $\left(\right.$ cmolc kg $\left.^{-1}\right)$ & 10.12 \\
\hline Organic Matter $\left(\mathrm{g} \mathrm{kg}^{-1}\right)$ & 5.53 \\
\hline $\mathrm{KCl}-\mathrm{N}\left(\mathrm{mg} \mathrm{kg}^{-1}\right)$ & 12.12 \\
\hline Olsen's-P $\quad\left(\mathrm{mg} \mathrm{kg}^{-1}\right)$ & 15.23 \\
\hline $\mathrm{NH}_{4} \mathrm{OAc}-\mathrm{K}\left(\mathrm{mg} \mathrm{kg}^{-1}\right)$ & 44.65 \\
\hline $\mathrm{CaCl}_{2}-\mathrm{Si} \quad\left(\mathrm{mg} \mathrm{kg}^{-1}\right)$ & 15.27 \\
\hline
\end{tabular}

* one hectogram $(\mathrm{hg})=100 \mathrm{~g}$

The spectra of biochar functional groups from Fourier Transform Infrared Spectra (FTIR) has been obtained in the wavenumber region of 4,000 $400 \mathrm{~cm}^{-1}$ using FTIR spectrometer (Spectrum 100, Perkin Elmer, USA). The scanning electron microscopy coupled with energy dispersive $\mathrm{X}$-ray analysis (SEM-EDAX) (JEOL JSM-6390LV, Japan) was used to determine the chemical composition of biochar. The specific surface area of biochar was analyzed using the BET surface area analyzer (Autosorb AS-1MP, Quanta 
chrome, USA). The physical sorption analysis was done with $\mathrm{N}_{2}$ adsorptiondesorption measurements at liquid $\mathrm{N}_{2}$ temperature $\left(-196{ }^{\circ} \mathrm{C}\right)$. Chlorophyll content of leaves was determined by chlorophyll meter (model SPAD-502, Minolta Corp, Ramsey, N.J.).

\section{Statistical analysis:}

All data were statistically analyzed according to the variance of analysis technique for the simple design using the MSTATC software package. The significant differences between the mean values of treatments were achieved by the LSD method.

\section{RESULTS \& DISCUSSION}

\section{Characterization of bagasse biochar:}

Scanning electron microscope (SEM) images and EDS peaks of biochar are shown in Figs. (1a-1c). Figure (1a, 1b) describe biochar under the camera of the scanning electron microscope. Figure (1c) indicates to the chemical composition of biochar by a unit of EDS analysis where biochar EDS noticed that biochar has contained $\mathrm{C}, \mathrm{O}, \mathrm{Si}, \mathrm{Na}, \mathrm{Ca}, \mathrm{K}$ and $\mathrm{Mg}$ of about 71.68, 23.87, $1.53,1.15,0.78,0.61$ and $0.38 \mathrm{~g} \mathrm{hg}^{-1}$ wt., respectively. These results notice that biochar maybe contribute increase the fertility status of investigated sandy soils. Additionally, FTIR spectra (Fig. 2a) analysis for biochar indicates that it contains a large number of functional groups such as hydroxyl $(\mathrm{OH})$, ketone $(\mathrm{C}=\mathrm{O})$, carboxyl $(\mathrm{COOH})$, carbonyl and silicon groups, siloxane $(\mathrm{Si}-\mathrm{O}-\mathrm{Si})$ and silanol $(\mathrm{Si}-\mathrm{O}, \mathrm{Si}-\mathrm{H})$. The intensity of broadband at the range of 3670-2750 $\mathrm{cm}^{-1}$ (maximum peak at $3400 \mathrm{~cm}^{-1}$ ) in the produced biochar from bagasse. This peak represents the stretching vibration of $\mathrm{OH}$ groups. Also, the groups of carboxyl, carbonyl, and ketone appeared between 3000 to $1500 \mathrm{~cm}^{-1}$. Also, the silicon groups that appeared between 1200 to $300 \mathrm{~cm}^{-1}$. These results indicate to the presence of a large number of active groups in the produced biochar at a temperature of below $500^{\circ} \mathrm{C}$ and these results are consistent with (Zolfi Bavariani et al., 2019). The specific surface area (SSA) of the biochar was measured using a multiple-point BET surface area analyzer. The data of SSA measurement are shown in Fig. (2b). The SSA and BET of the produced biochar were $123.74, \mathrm{~m}^{2} \mathrm{~g}^{-1}$. This result indicates that biochar has a high specific surface area that could lead to higher hold water capacity and building up nutrients status in investigated sandy soil. 


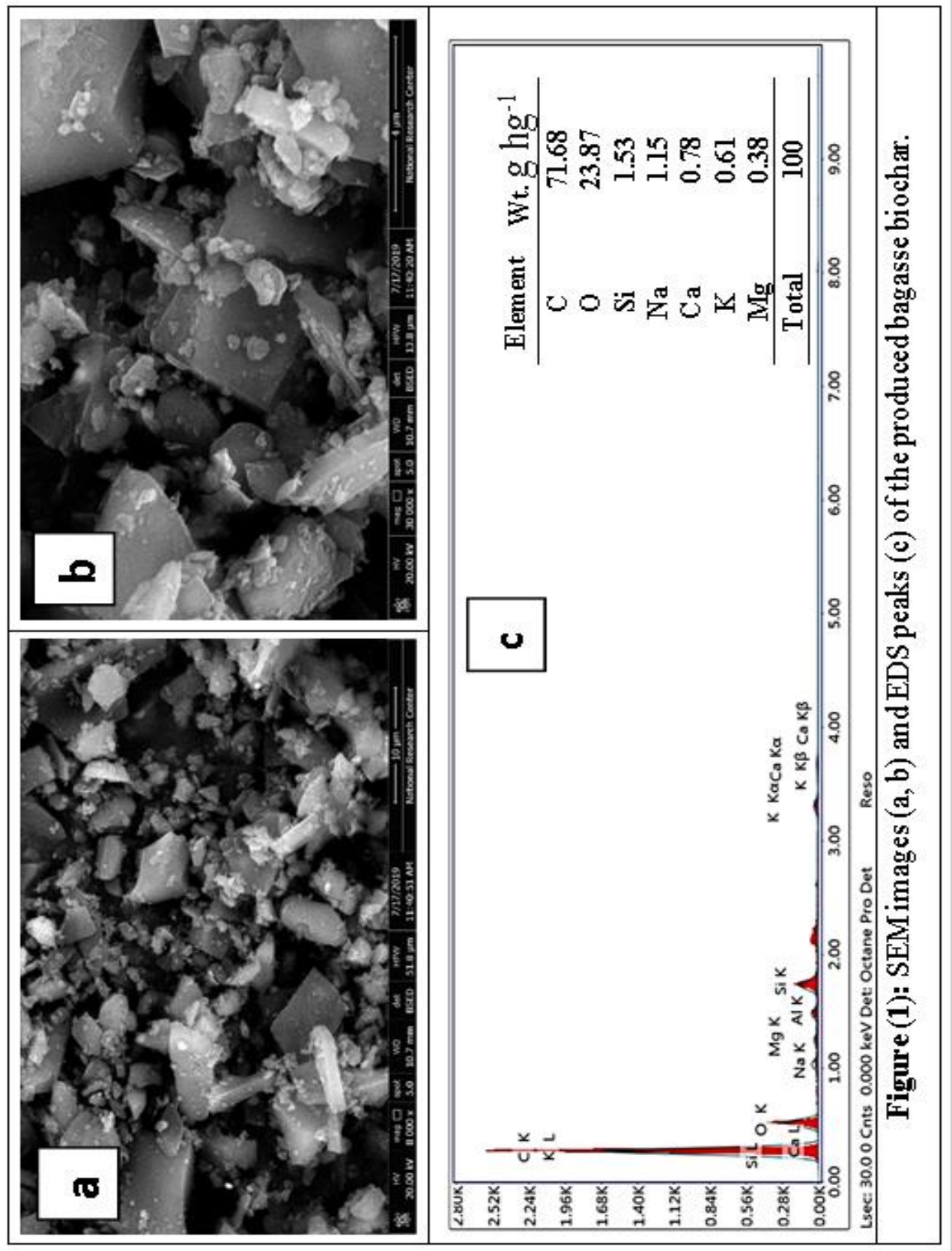




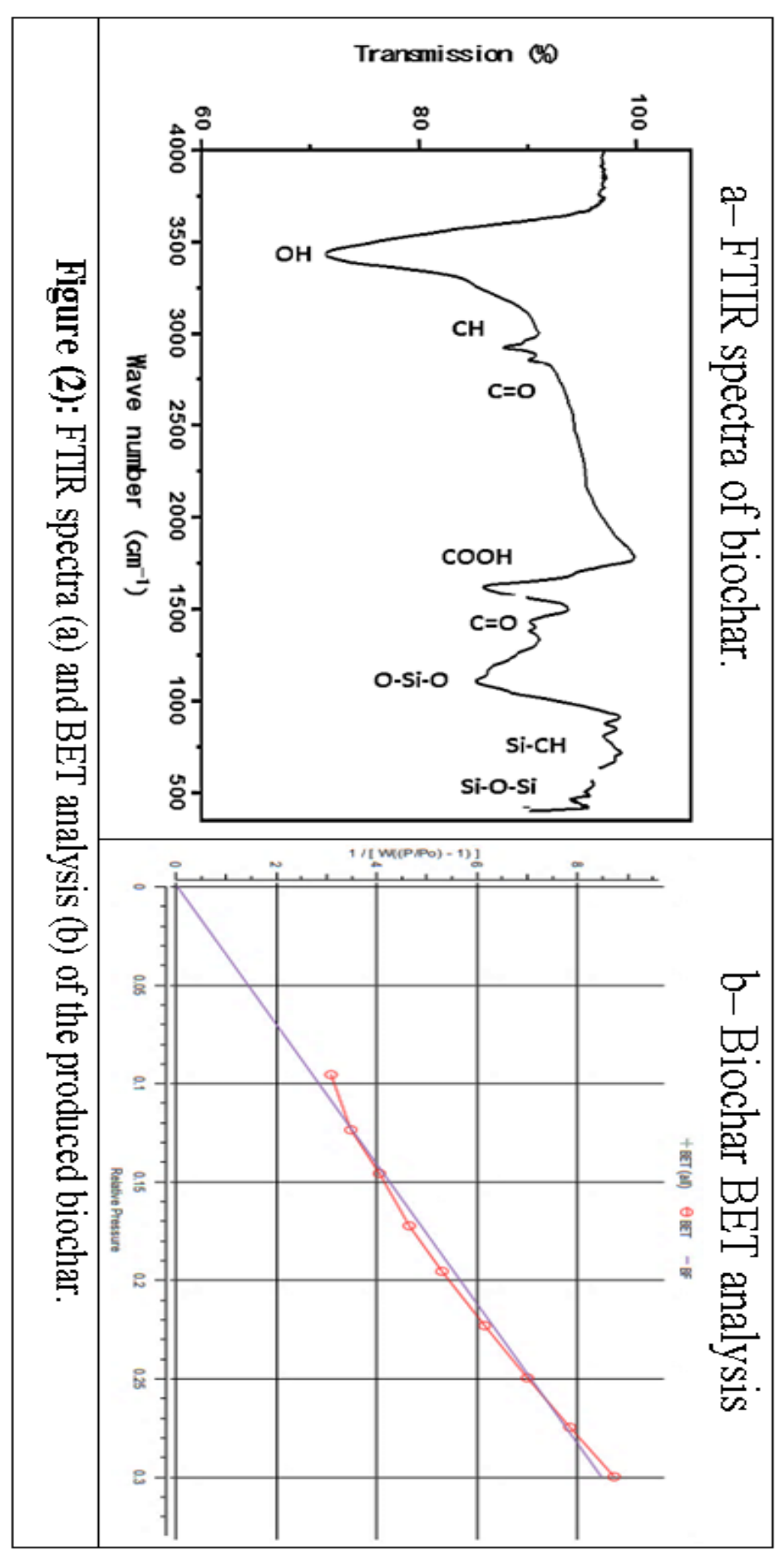




\section{Effects of biochar application on some physio-chemical properties:}

Generally, biochar addition improved soil physio-chemical properties. Biochar addition was led to a clear significant decrease in soil densities with increasing the biochar application rates (Table 3). The decreases values of soil PD and BD were 7.55, 16.60, 23.77, 29.06\% and 12.07, 21.84, 33.91, 39.66\% for the $1.0,2,5,10.0 \%$, respectively. Additionally, the soil porosity was increased compared to check treatment. Soil-WHC was significantly increased from $33 \mathrm{~g}$ $\mathrm{hg}^{-1}$ to $58 \mathrm{~g} \mathrm{hg}^{-1}$ for 0.0 and $10.0 \%$ biochar treatments.

The increasing of WHC value was about $75 \%$ for the $10.0 \%$ biochar treatment. Also, Soil-OM was increased up to $10.1 \mathrm{~g} \mathrm{hg}^{-1}$ with the high biochar treatment. Similar results were presented by (Duarte et al., 2019), (Kanouo et al., 2019), (Zhou et al., 2019) and (Liu et al., 2020). They indicated that the improvements in some physical and chemical soil properties when biochar was used in agriculture. Zhou et al. (2019) noted that biochar has the potential to modify soil structure and soil hydraulic properties because of its small particle density, highly porous structure, grain size distribution and surface chemistry. Biochar as a soil amendment has received much attention because of its capacity to modify and adapt many soil physical, chemical and biological properties (Blanco-Canqui, 2017). Since biochar has a bulk density much lower than that of mineral soils and, therefore, application of biochar may increase the volume of unit weight of soil and thereby reduces the bulk density of the soil. The most interesting result is that even small, and not statistically significant, modifications in soil bulk density may lead to appreciable variations of the soil water retention (Castellini et al., 2015; Pandian et al., 2016; Liu et al., 2020; Martos et al., 2020). Besides, the decrease in bulk density of biochar-amended soil could be one of the indicators of enhancement of soil structure or aggregation and aeration and could be soil specific (Atkinson et al., 2010; Pandian et al., 2016). The experimental results revealed that biochar application positively influenced the physical properties of the soil, which in turn improve crop growth and yield by increasing crop water availability in the semi-arid environments (Liu et al., 2020; Martos et al., 2020). Also, EC values (soil paste extract) and $\mathrm{pH}$ values (soil paste) were not significantly affected. Biochar may cause an increase in soil $\mathrm{pH}$ depending on many factors, including the type of residue from which the biochar is made. These results are consistent with Martos et al. (2020) that indicated to the biochar can adjust the soil $\mathrm{pH}$ and increase the nutrient's availability in the soil solution and preserve these nutrients for plant uptake. The decrease or increase of the soil-pH values depends on the source of the used materials of the biochar. This can be attributed to the nature and source of biochar (Atkinson et al., 2010; Liu et al., 2020; Martos et al., 2020). The biochar has some positive properties such as the increase in porosity, increase in the specific surface area, 
Table (3): Some physio-chemical of the sandy soil after sowing.

\begin{tabular}{cccccccc}
\hline $\begin{array}{c}\text { Biochar } \\
\text { rates }(\%)\end{array}$ & $\begin{array}{c}\mathbf{P D} \\
\left(\mathbf{g ~ c m}^{-3}\right)\end{array}$ & $\begin{array}{c}\mathbf{B D} \\
\left(\mathbf{g ~ c m}^{-3}\right)\end{array}$ & $\begin{array}{c}\text { Porosity } \\
\left(\mathbf{g ~ h g}^{-1}\right)\end{array}$ & $\begin{array}{c}\mathbf{W H C} \\
\left(\mathbf{g ~ h g}^{-1}\right)\end{array}$ & $\begin{array}{c}\mathbf{O M} \\
\left(\mathbf{g ~ h g}^{-1}\right)\end{array}$ & $\mathbf{p H}$ & $\begin{array}{c}\mathbf{E C} \\
\left(\mathbf{d S ~ m}^{-\mathbf{1})}\right.\end{array}$ \\
\hline $\mathbf{0 . 0}$ & $2.65^{\mathrm{a}}$ & $1.74^{\mathrm{a}}$ & $34.34^{\mathrm{e}}$ & $33.12^{\mathrm{e}}$ & $0.81^{\mathrm{d}}$ & 7.33 & 1.34 \\
$\mathbf{1 . 0}$ & $2.45^{\mathrm{b}}$ & $1.53^{\mathrm{b}}$ & $37.55^{\mathrm{d}}$ & $37.33^{\mathrm{d}}$ & $1.11^{\mathrm{d}}$ & 7.35 & 1.41 \\
$\mathbf{2 . 5}$ & $2.21^{\mathrm{c}}$ & $1.36^{\mathrm{c}}$ & $38.46^{\mathrm{c}}$ & $43.21^{\mathrm{c}}$ & $2.70^{\mathrm{c}}$ & 7.32 & 1.43 \\
$\mathbf{5 . 0}$ & $2.01^{\mathrm{d}}$ & $1.15^{\mathrm{d}}$ & $43.07^{\mathrm{b}}$ & $53.31^{\mathrm{b}}$ & $5.09^{\mathrm{b}}$ & 7.43 & 1.42 \\
$\mathbf{1 0 . 0}$ & $1.88^{\mathrm{e}}$ & $1.05^{\mathrm{e}}$ & $44.15^{\mathrm{a}}$ & $58.14^{\mathrm{a}}$ & $10.01^{\mathrm{a}}$ & 7.43 & 1.43 \\
\hline LSD 0.05 & $\mathbf{0 . 0 0 8}$ & $\mathbf{0 . 0 0 4}$ & $\mathbf{0 . 7 4 2}$ & $\mathbf{3 . 5 0 1}$ & $\mathbf{0 . 3 8 2}$ & $\mathbf{N S}$ & $\mathbf{N S}$ \\
\hline
\end{tabular}

NS: Not significant.

increase the WHC, increase the functional group's number, increase the CEC and available contents elements in the soil.

\section{Influences of biochar application on maize growth and some nutrients in maize roots and shoots:}

Data presented in Table 4 indicate that the growth parameters of maize as influenced by biochar application. Total-chlorophyll contents in maize leaves were significantly increased with increasing in biochar application rates. Chlorophyll values were increased by $17.84,36.26,40.98,44.26 \mathrm{~g} \mathrm{hg}-1$ for 1 , 2.5, 5 and $10 \%$ biochar, respectively. Also, biomass content of maize plants increased in all application rates compared to the check treatment with increments of the values were $69.55,142.95,186.22,258.97 \mathrm{~g}$ hg-1 for 1, 2.5, 5 and $10 \%$ biochar, respectively. Maize roots and shoots were significantly improved with increasing biochar application rates as shown in Fig. (3).

Generally, the nutrients contents in maize increased as shown in Table (5) and Fig. (4). N, P, K and Si contents were significantly increased in both roots and shoots. For roots, the maximum values of 1.43, 0.08, $1.34 \mathrm{~g}$ hg-1 with increases of 267, 60 and $20.7 \%$ for N, P and K were realized by using $10 \%$ biochar rate, respectively while the best $\mathrm{Si}$ value $1.77 \%$ with increments of $293 \%$ was achieved at biochar level of 5\% as compared to check treatment. The same treatment was found with respect to the above-mentioned nutrients content for maize shoots where the better values of $1.61,0.08,1.31$ and $4.98 \mathrm{~g}$ hg-1 with increments of 224, 35.3, 12.9 and $1.88 \%$ were obtained, respectively when biochar rate of $10 \%$ was applied. It can say that the positive effect of produced bagasse biochar on soil physio-chemical properties can be thoroughly the following: (1) decreasing soil bulk density and increasing WHC because biochar has low density (less than $0.9 \mathrm{~g} \mathrm{~cm}-3$ ), (2) biochar has many functional groups, therefore, it has high CEC, the ability for saving nutrients from leaching, high specific surface area, acts as a store for elements, especially 
Table 4: Effect of biochar on some growth parameters of maize grown in sandy soil.

\begin{tabular}{ccccc}
\hline $\begin{array}{c}\text { Biochar } \\
\text { rates }(\%)\end{array}$ & $\begin{array}{c}\text { Chlorophyll } \\
\text { content }\end{array}$ & $\begin{array}{c}\text { Biomass } \\
(\mathbf{g})\end{array}$ & $\begin{array}{c}\text { Root depth } \\
(\mathbf{c m})\end{array}$ & $\begin{array}{c}\text { Maize height } \\
(\mathbf{c m})\end{array}$ \\
\hline $\mathbf{0 . 0}$ & $15.25^{\mathrm{c}}$ & $3.12^{\mathrm{e}}$ & $6.33^{\mathrm{c}}$ & $15.00^{\mathrm{c}}$ \\
$\mathbf{1 . 0}$ & $17.97^{\mathrm{b}}$ & $5.29^{\mathrm{d}}$ & $9.27^{\mathrm{b}}$ & $17.23^{\mathrm{b}}$ \\
$\mathbf{2 . 5}$ & $20.78^{\mathrm{a}}$ & $7.58^{\mathrm{c}}$ & $13.37^{\mathrm{a}}$ & $23.17^{\mathrm{a}}$ \\
$\mathbf{5 . 0}$ & $21.50^{\mathrm{a}}$ & $8.93^{\mathrm{b}}$ & $12.03^{\mathrm{ab}}$ & $23.83^{\mathrm{a}}$ \\
$\mathbf{1 0 . 0}$ & $22.00^{\mathrm{a}}$ & $11.20^{\mathrm{a}}$ & $13.60^{\mathrm{a}}$ & $24.00^{\mathrm{a}}$ \\
\hline LSD 0.05 & $\mathbf{1 . 6 4 0}$ & $\mathbf{0 . 0 3 1}$ & $\mathbf{2 . 8 1 0}$ & $\mathbf{1 . 3 6 0}$ \\
\hline
\end{tabular}

Table (5): Effect of biochar on contents of some nutrients by maize plants grown in sandy soil.

\begin{tabular}{|c|c|c|c|c|c|c|c|c|}
\hline \multirow{2}{*}{$\begin{array}{c}\text { Biochar } \\
\text { rates }(\%)\end{array}$} & \multicolumn{4}{|c|}{ Maize roots } & \multicolumn{4}{|c|}{ Maize shoots } \\
\hline & $\begin{array}{c}\mathbf{N} \\
\left(\mathrm{g} \mathrm{hg}^{-1}\right)\end{array}$ & $\begin{array}{c}\mathbf{P} \\
\left(\mathrm{g} \mathrm{hg}^{-1}\right)\end{array}$ & $\begin{array}{c}\mathrm{K} \\
\left(\mathrm{g} \mathrm{hg}^{-1}\right)\end{array}$ & $\begin{array}{c}\mathbf{S i} \\
\left(\mathbf{g ~ h g}^{-1}\right)\end{array}$ & $\begin{array}{c}\mathbf{N} \\
\left(\mathrm{g} \mathrm{hg}^{-1}\right)\end{array}$ & $\begin{array}{c}\mathbf{P} \\
\left(\mathrm{g} \mathrm{hg}^{-1}\right)\end{array}$ & $\begin{array}{c}\mathrm{K} \\
\left(\mathrm{g} \mathrm{hg}^{-1}\right)\end{array}$ & $\begin{array}{c}\mathbf{S i} \\
\left(\mathrm{g} \mathrm{hg}^{-1}\right)\end{array}$ \\
\hline 0.0 & $0.39^{\mathrm{e}}$ & $0.05^{\mathrm{c}}$ & $1.11^{\mathrm{b}}$ & $0.96^{\mathrm{b}}$ & $0.38^{\mathrm{e}}$ & $0.06^{\mathrm{ab}}$ & $1.16^{\mathrm{C}}$ & $1.73^{\mathrm{d}}$ \\
\hline 1.0 & $0.88^{\mathrm{d}}$ & $0.05^{\mathrm{c}}$ & $1.12^{\mathrm{ab}}$ & $1.00^{\mathrm{b}}$ & $0.98^{\mathrm{d}}$ & $0.06^{\mathrm{ab}}$ & $1.16^{\mathrm{c}}$ & $2.02^{\mathrm{d}}$ \\
\hline 2.5 & $0.98^{\mathrm{c}}$ & $0.06^{\mathrm{b}}$ & $1.33^{\mathrm{a}}$ & $3.75^{\mathrm{a}}$ & $1.23^{\mathrm{c}}$ & $0.06^{\mathrm{ab}}$ & $1.16^{\mathrm{c}}$ & $3.39^{\mathrm{c}}$ \\
\hline 5.0 & $1.29^{\mathrm{b}}$ & $0.06^{\mathrm{b}}$ & $1.33^{\mathrm{a}}$ & $3.77^{\mathrm{a}}$ & $1.44^{\mathrm{b}}$ & $0.08^{\mathrm{a}}$ & $1.27^{\mathrm{b}}$ & $3.95^{\mathrm{b}}$ \\
\hline 10.0 & $1.43^{\mathrm{a}}$ & $0.08^{\mathrm{a}}$ & $1.34^{\mathrm{a}}$ & $3.72^{\mathrm{a}}$ & $1.61^{\mathrm{a}}$ & $0.08^{\mathrm{a}}$ & $1.31^{\mathrm{a}}$ & $4.98^{\mathrm{a}}$ \\
\hline LSD 0.05 & 0.020 & 0.007 & 0.010 & 0.501 & 0.010 & 0.007 & 0.008 & 0.482 \\
\hline
\end{tabular}

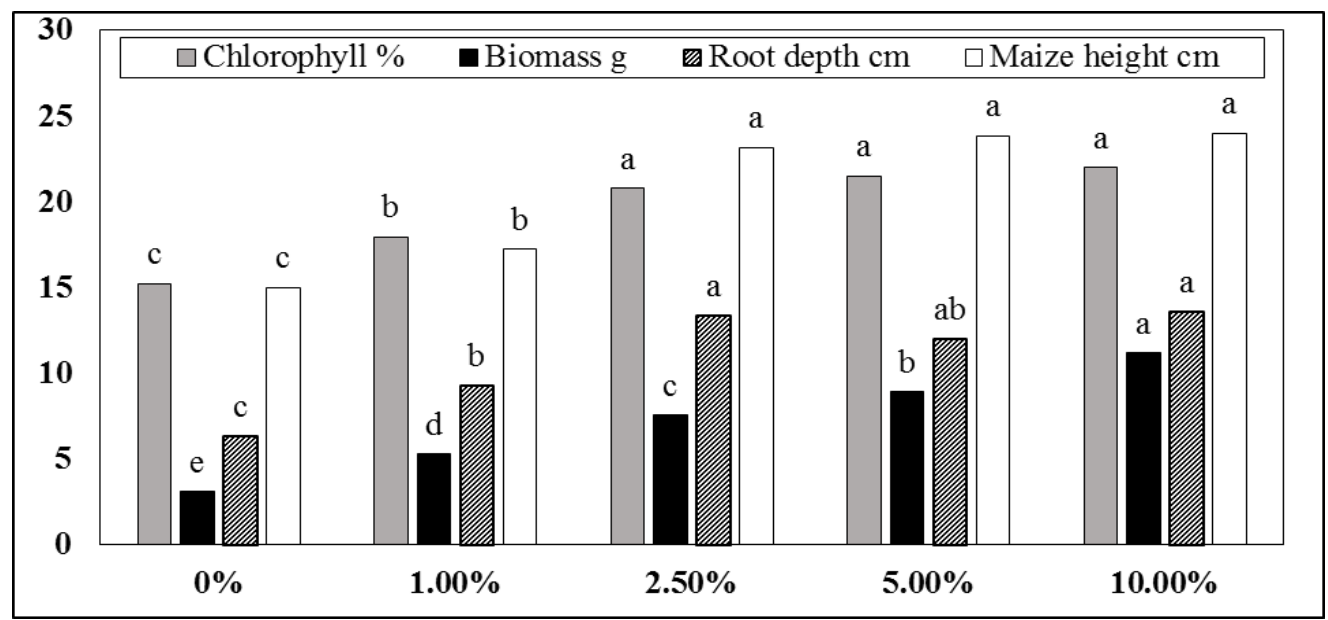

Fig. (3): Influence of biochar application rates on some growth parameters of maize plants grown in sandy soil. 


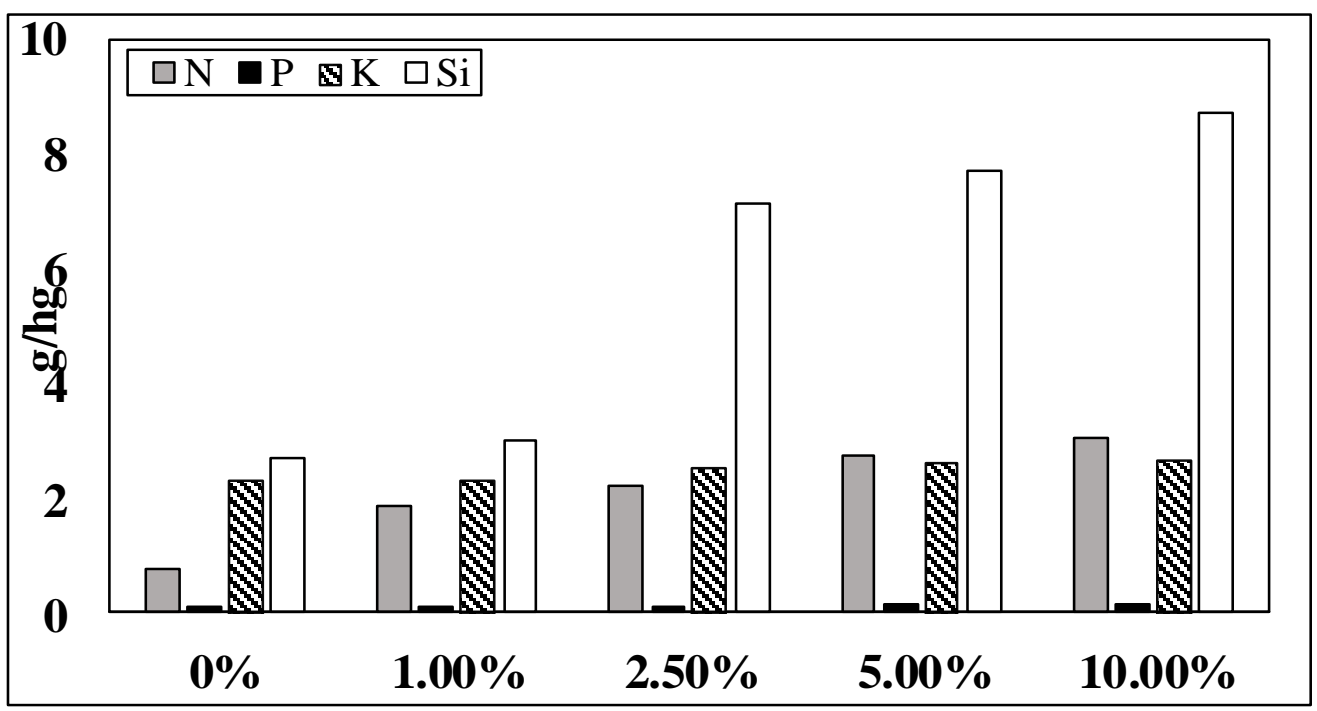

Fig. (4): Influence of biochar application rates on some nutrients uptake in maize plants grown in sandy soil.

needed to plants and contains it Si elements. These results are reported in several studies according to (Jeffery et al., 2011; Kammann \& Graber, 2015; Abbas et al., 2018; Liu et al., 2020; Martos et al., 2020).

Conclusively, biochar was made from bagasse using kiln technology. Biochar application to sandy soil improving soil physio-chemical properties such as PD, BD, porosity, WHC, OM, N, P, K and Si. Also, biochar led to improving maize plants growth, chlorophyll content, roots depth and maize height. It can be concluded that the use of biochar could cause a significant increase in maize plants growth and nutrient uptake in sandy soils with application rate up to $10 \%$ of bagasse biochar.

\section{ACKNOWLEDGMENT}

Thanks to all staff members at Soil and Water Science Department, Faculty of Technology \& development, Zagazig University for all their support.

\section{REFERENCES}

Abbas, T., Rizwan, M., Ali, S., Adrees, M., Ziaur-Rehman, M., Qayyum, M. F., Ok, Y. S. and Murtaza, G. (2018). Effect of biochar on alleviation of cadmium toxicity in wheat (Triticum aestivum L.) grown on Cd-contaminated saline soil. Environmental Science and Pollution Research, 25(26), 25668-25680. https://doi.org/10.1007/s11356-017-8987-4. 
Aslam, Z., Khalid, M. and Aon, M. (2014). Impact of biochar on soil physical properties. Scholarly Journal of Agricultural Science, 4(5), 280-284. https://doi.org/10.1111/j.1365-2486.2009.02044.x.Novak.

Atkinson, C. J., Fitzgerald, J. D. and Hipps, N. A. (2010). Potential mechanisms for achieving agricultural benefits from biochar application to temperate soils. A review: Plant and Soil, 337(1-2), 1-18. https://doi.org/10.1007/s11104-010-0464-5.

Blanco-Canqui, H. (2017). Biochar and soil physical properties. Soil Science Society of America Journal, 84, 687. https:// doi.org/ 10.2136/ sssaj 2017.01.0017.

Castellini, M., Giglio, L., Niedda, M., Palumbo, A. D. and Ventrella, D. (2015). Impact of biochar addition on the physical and hydraulic properties of a clay soil. Soil and Tillage Research, 154, 1-13. https://doi.org/10.1016/j.still.2015.06.016.

Duarte, S., Glaser, B. and Pellegrino Cerri, C. (2019). Effect of biochar particle size on physical, hydrological and chemical properties of loamy and sandy tropical soils. Agronomy, 9(4), 165. https://doi.org/10. 3390/ agronomy 9040165.

Estefan, G., Rolf S. and Rayan J. (2013). Methods of soil, plant and water analysis: International Center for Agric.Research in Dry Areas, 1-244.

Farias, W. M., Figueiredo, C. C. de, Coser, T. R., Vale, A. T. and Schneider, B. G. (2018). Is sewage sludge biochar capable of replacing inorganic fertilizers for corn production? Evidence from a two-year field experiment. Archives of Agronomy and Soil Science, 64(4), 505-519. https://doi.org/10.1080/03650340.2017.1360488.

Glaser, B., Lehmann, J. and Zech, W. (2002). Ameliorating physical and chemical properties of highly weathered soils in the tropics with charcoal - a review. Biology and Fertility of Soils, 35(4), 219-230. https:// doi. org/ 10.1007/s00374-002-0466-4.

Geohack (2020). Available online via https://geohack.toolforge.org/.

Huang, M., Zhang, Z., Zhu, C., Zhai, Y. and Lu, P. (2019). Effect of biochar on sweet corn and soil salinity under conjunctive irrigation with brackish water in coastal saline soil. Scientia Horticulturae, 250, 405-413. https:// doi. org/10.1016/J.Scienta.2019.02.077.

Jeffery, S., Verheijen, F. G. A., van der Velde, M. and Bastos, A. C. (2011). A quantitative review of the effects of biochar application to soils on crop productivity using meta-analysis. Agriculture, Ecosystems and Environment, 144(1), 175-187. https:// doi.org/https: //doi.org/ 10. 1016/ J.Agee.2011.08.015. 
Joseph, S. and Lehmann, J. (2009). Biochar For Environmental Management: Science And Technology. Issue 631.422 B615bi). London, GB: Earthscan.

Kammann, C. and Graber, E. R. (2015). Biochar effects on plant ecophysiology. Biochar for Environmental Management: Science, Technology and Implementation, 391-420.

Kanouo, D., B. M., Allaire, S. E. and Munson, A. D. (2019). Quantifying the influence of eucalyptus bark and corncob biochars on the physicochemical properties of a tropical oxisol under two soil tillage modes. International Journal of Recycling of Organic Waste in Agriculture, 8(S1), 211-224. https://doi.org/10.1007/s40093-019-00292-w.

Lehmann, J., Rillig, M. C., Thies, J., Masiello, C. A., Hockaday, W. C., and Crowley, D. (2011). Biochar effects on soil biota - a review. Soil Biology and Biochemistry, 43(9), 1812-1836. https:// doi.org/ 10.1016/ j.soilbio.2011.04.022.

Liu, D., Feng, Z., Zhu, H., Yu, L., Yang, K., Yu, S., Zhang, Y. and Guo, W. (2020). Effects of corn straw biochar application on soybean growth and alkaline soil properties. Bio Resources, 15(1), 1463-1481. https:// doi.org/ 10. 15376/biores.15.1.1463-1481.

Lu, S. G., Sun, F. F. and Zong, Y. T. (2014). Effect of rice husk biochar and coal fly ash on some physical properties of expansive clayey soil (Vertisol). CATENA, 114, 37-44. https:// doi.org/ 10. 1016/ j.catena. 2013.10.014.

Martos, S., Mattana, S., Ribas, A., Albanell, E. and Domene, X. (2020). Biochar application as a win-win strategy to mitigate soil nitrate pollution without compromising crop yields: a case study in a Mediterranean calcareous soil. Journal of Soils and Sediments, 20(1), 220-233. https://doi.org/10.1007/s11368-019-02400-9.

Nelissen, V., Ruysschaert, G., Manka'Abusi, D., D'Hose, T., De Beuf, K., Al-Barri, B., Cornelis, W. and Boeckx, P. (2015). Impact of a woody biochar on properties of a sandy loam soil and spring barley during a two-year field experiment. European Journal of Agronomy, 62: 65-78. https://doi.org/10.1016/j.eja.2014.09.006.

Novotny, E. H., Maia, C. M. B. de F., Carvalho, M. T. de M., and Madari, B. E. (2015). Biochar: pyrogenic carbon for agricultural use . A critical review. Rev. Bras. Ciênc. Solo, 39(2), 321-344. https:// doi. org/ 10.1590/01000683rbcs20140818 
Pandey, D., Daverey, A. and Arunachalam, K. (2020). Biochar: Production, properties and emerging role as a support for enzyme immobilization. Journal of Cleaner Production, 255, 120267. https:// doi.org/ 10. 1016 /j.jclepro.2020.120267.

Pandian, K., Subramaniayan, P., Gnasekaran, P. and Chitraputhirapillai, S. (2016). Effect of biochar amendment on soil physical, chemical and biological properties and groundnut yield in rainfed Alfisol of semi-arid tropics. Archives of Agronomy and Soil Science, 62(9), 1293-1310. https://doi.org/10.1080/03650340.2016.1139086.

Parkinson, J. A. and Allen, S. E. (1975). A wet oxidation procedure suitable for the determination of nitrogen and mineral nutrients in biological material. Communications in Soil Science and Plant Analysis, 6(1), 1-11. https://doi.org/10.1080/00103627509366539.

Sarfraz, R., Hussain, A., Sabir, A., Ben Fekih, I., Ditta, A. and Xing, S. (2019). Role of biochar and plant growth promoting rhizobacteria to enhance soil carbon sequestration. A review. Environmental Monitoring and Assessment, 191(4). https://doi.org/10.1007/s10661-019-7400-9.

Sohi, S. P., Krull, E., Lopez-Capel, E. and Bol, R. (2010). A review of biochar and its use and function in soil. In Advances in agronomy (Vol. 105, pp. 47-82). Elsevier.

Teßin A. K. (2016). Biochar in soil: effect on physical, chemical and hydrological properties in differently textured soils. Master's degree program Agro-Environmental Management. Department of Agroecology, AU.

Zhou, X., Qiao, M., Su, J. Q., Wang, Y., Cao, Z. H., Cheng, W. D. and Zhu, Y. G. (2019). Turning pig manure into biochar can effectively mitigate antibiotic resistance genes as organic fertilizer. Science of The Total Environment, 649, 902-908. https://doi. org/ 10. 1016/ j.scitotenv .2018.08.368.

Zolfi Bavariani, M., Ronaghi, A. and Ghasemi, R. (2019). Influence of pyrolysis temperatures on FTIR analysis, nutrient bioavailability, and agricultural use of poultry manure biochars. Communications in Soil Science and Plant Analysis, 50(4), 402-411. https://doi.org/ 10. 1080/ 00103624.2018.1563101. 


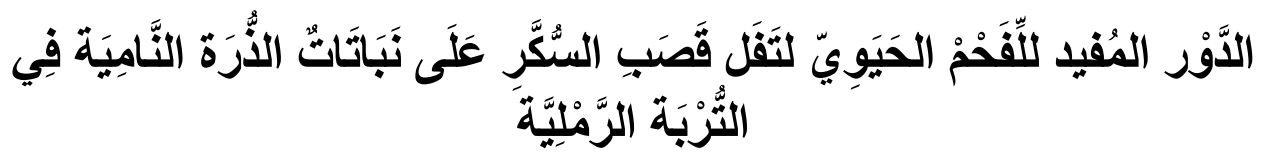

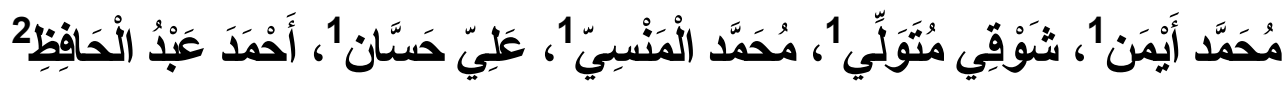

1- - كلية التكنولوجيا والتنمية، جامعة الزقازيق، مصر.

2- كلية الزر اعة، جامعة الو ادي الجديد، مصر.

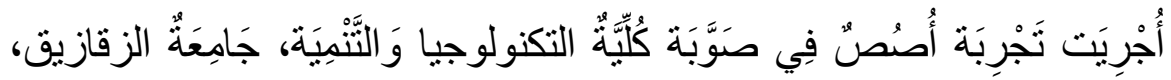

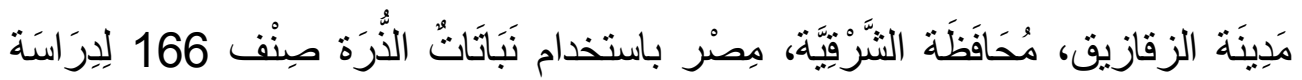

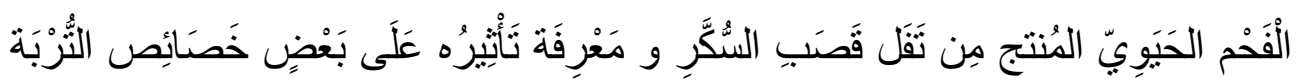

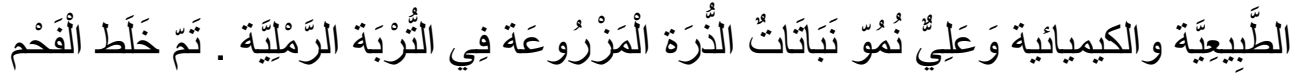

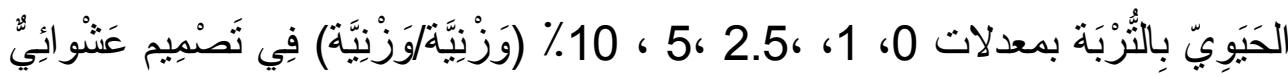

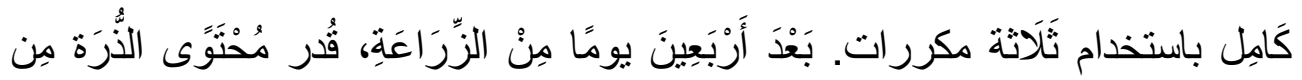

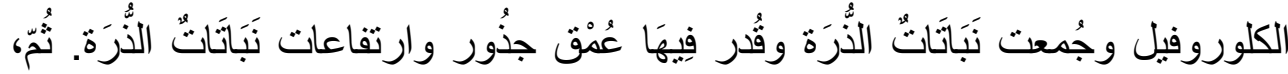

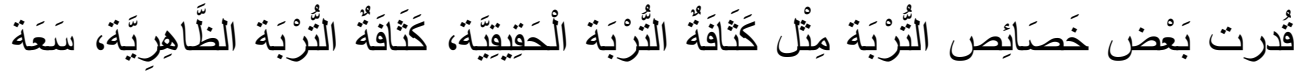

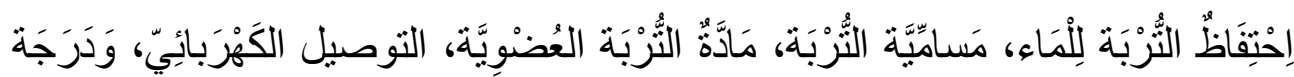

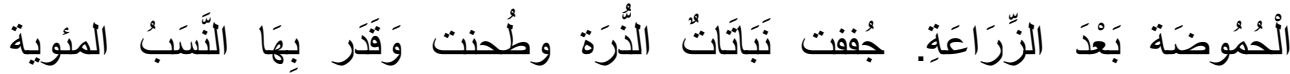

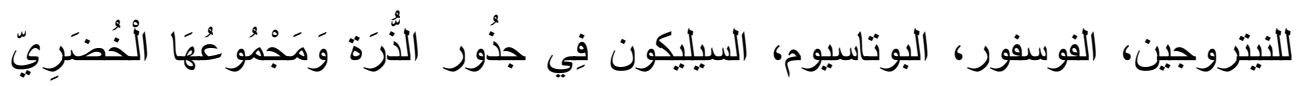

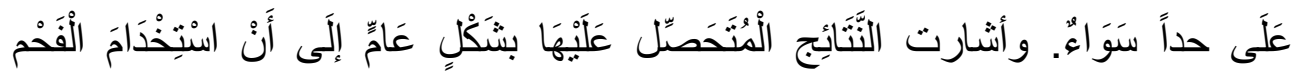

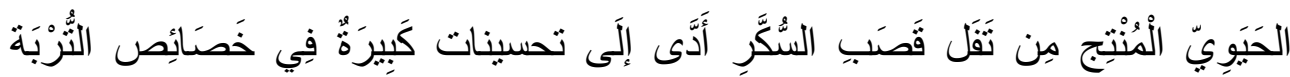

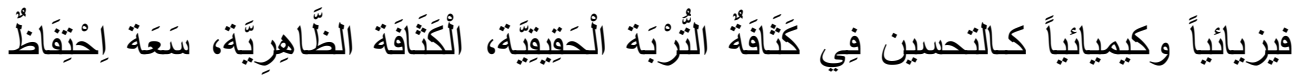

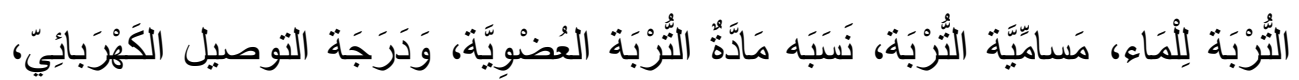

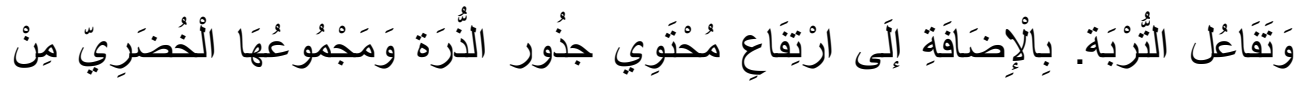


عَنَاصِرَ النبترورجين، الفوسفور، البوتاسيوم، السيليكون بِشَكْل مَعْنَوِيٌ. كَمَا أَدَّى الْفَحْم

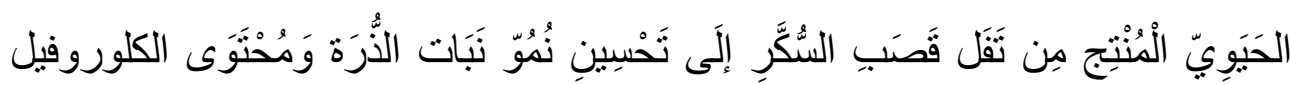

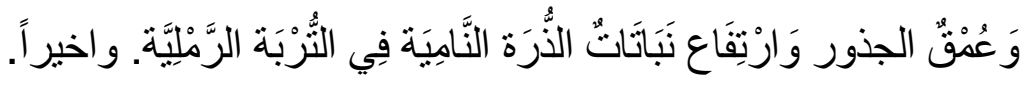

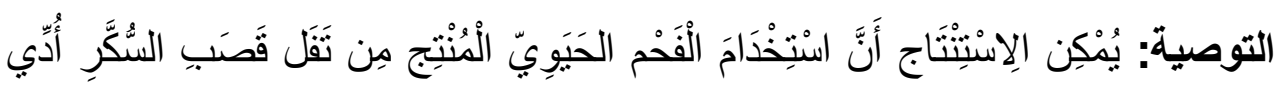

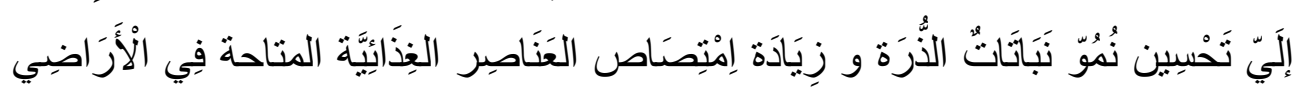

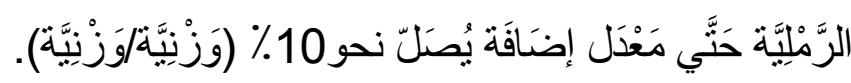

